\title{
Calcium Mobilization and Inhibition of Akt Reduced the Binding of PEO-1 Cells to Fibronectin
}

\section{$\mathrm{Ca}^{2+}$ Mobilizasyonu ve Akt İnhibisyonu ile PEO-1 Hücrelerinin Fibronektine Bağlanmasında Azalma}

\author{
(D) Seda Mehtap SARI KILIÇASLAN*, (D) Aysun AYRIM², (D) Elif APAYDIN³ (D) Zerrin INCESU ${ }^{4}$ \\ 'Anadolu University, Faculty of Education, Department of Primary Education, Eskișehir, Turkey \\ ${ }^{2}$ Eskișehir Osmangazi University, Institute of Life Sciences, Eskişehir, Turkey \\ ${ }^{3}$ Anadolu University, Institute of Life Sciences, Eskișehir, Turkey \\ ${ }^{4}$ Anadolu University, Faculty of Pharmacy, Department of Biochemistry, Eskişehir, Turkey
}

\begin{abstract}
Objectives: To investigate the effects of intracellular calcium $\left(\mathrm{Ca}^{2+}\right)$ mobilization, $\beta$-catenin and Akt signal pathways after the binding of metastatic ovarian cells to fibronectin.

Materials and Methods: The expression levels of $\alpha 4 \beta 1$ and $\alpha v \beta 6$ integrin were determined using $\alpha 4, \beta 1, \alpha v$, and $\beta 6$ antibodies using flow cytometry on PEO-1 cells. The effect of [Ca $\left.{ }^{2+}\right]$ i on cell adhesion capacity was investigated using RTCA after stimulating PEO-1 cells using thapsigargin and tunicamycin. The binding rate of PEO-1 cells to fibronectin was also investigated in the presence of either different concentrations of cardamonin, which inhibits the accumulation of $\beta$-catenin, or different concentrations of FPA 124, which is a specific inhibitor for the PKB/Akt signal pathway, using RTCA.

Results: RTCA analysis results showed that increasing [ $\left.\mathrm{Ca}^{2+}\right]$ i through leakage of the calcium pool was strongly effective on PEO-1 cell binding to fibronectin. Extracellular calcium influx also reduced the binding of PEO-1 cells. Cell binding to fibronectin was also inhibited with a ratio of $64 \%$ in the presence of $100 \mu \mathrm{M}$ cardamonin compared with untreated control cells. Finally, it was found that PKB/Akt inhibition with $15 \mu \mathrm{M}$ FPA 124 decreased the binding of PEO-1 cells to fibronectin with a ratio of $88 \%$ compared with untreated control cells.
\end{abstract}

Conclusion: PEO-1 cell binding to fibronectin via integrins could be related to intracellular $\mathrm{Ca}^{2+}$ mobilization and Akt signaling.

Key words: Fibronectin, calcium, tunicamycin, ovarian cancer

\section{Öz}

Amaç: Metastatik ovaryum kanser hücrelerinin fibronektine bağlanmasından sonra, hücre içi Ca ${ }^{2+}$ mobilizasyonu, $\beta$-katenin ve Akt sinyal yollarının etkilerinin araştırılmasıdır.

Gereç ve Yöntemler: $\alpha 4 \beta 1$ ve $\alpha v \beta 6$ integrinlerin ekspresyon düzeyleri $\alpha 4, \beta 1, \alpha v$ vçe $\beta 6$ antikorları kullanılarak akım sitometrisi ile PEO-1 hücrelerinde tespit edilmiştir. $\left[\mathrm{Ca}^{2+}\right]^{\prime}$ un hücre adezyon kapasitesine etkisi, PEO-1 hücrelerinin tapsigargin ve tunikamisin ile uyarılmasından sonra RTCA kullanılarak araştırıldı. PEO-1 hücrelerinin fibronektine bağlanma oranı $\beta$-kateninin toplanmasını inhibe eden farklı kardamonin konsantrasyonları varlığında veya PKB/Akt sinyal yolu için spesifik inhibitör olan FPA 124'ün farklı konsantrasyonları için RTCA kullanılarak araştırıldı.

Bulgular: RTCA analiz sonuçları kalsiyum depolarından sızmasıyla artan [Ca+]'un PEO-1 hücrelerinin fibronektine bağlanmasını güçlü bir şekilde etkilediğini göstermiştir. Hücre dışı kalsiyum akımı PEO-1 hücrelerinin bağlanmasını azaltmıştır. $100 \mu \mathrm{M}$ kardamonin varlığında muamele edilmemiş kontrol hücrelerine göre hücrenin fibronektine bağlanması \%64 oranında inhibe olmuştur. Son olarak, 15 M FPA 124 ile PKB/Akt inhibisyonu da PEO-1 hücrelerinin fibronektine bağlanmasını \%88 oranında düșürdüğü bulunmuștur.

Sonuç: PEO-1 hücrelerinin integrinler aracılığı ile fibronektine bağlanmasının hücre içi $\mathrm{Ca}^{2+}$ mobilizasyonu ve Akt sinyali ile ilgili olabilir. Anahtar kelimeler: Fibronektin, kalsiyum, tunikamisin, ovaryum kanseri

*Correspondence: E-mail: smskilicaslan@anadolu.edu.tr, Phone: +90 222335 0580 / 3433 ORCID-ID: orcid.org/0000-0001-7547-5519 Received: 13.01.2017, Accepted: 06.04.2017

๑Turk J Pharm Sci, Published by Galenos Publishing House. 


\section{INTRODUCTION}

The cell adhesion molecules, integrins, activate outside-in signaling pathways necessary for cell invasion by mediating attachment between cells and the extracellular matrix (ECM). The integrins participate in cell morphology, migration, proliferation, differentiation, survival ${ }^{1,2}$, as well as apoptosis. Integrin-mediated cell attachment is necessary for cancer cell metastasis and invasion. Moreover, ECM-integrin signaling is said to have survival advantage in different types of cancer cells against many chemotherapeutic treatments. ${ }^{2}$ Studies on this topic are usually based on integrin expressions. Signal transduction mechanisms of integrins in ovarian cells, however, have not yet been explicitly investigated.

Cell-ECM adhesiveness is generally increased in human cancers, which allows cancer cells to destroy the histologic structure. Reduced cell-ECM adhesiveness is also important for cancer invasion and metastasis. ${ }^{3}$ Moreover, some studies showed that the adhesion capacity of highly metastatic cells could be reduced by inhibiting integrin expression or modifies the process that leads metastatic cells to anoikis, which is programmed cell death that is induced upon cell detachment from ECM. ${ }^{4,5} \alpha v$ integrin subunit-inhibition or $\alpha v$-knockdown was shown to inhibit the colonogenic and migratory ability of human prostate cancer cells in vitro and in vivo.,6 Accordingly, $\alpha v$ integrin is said to be a promising target for cancer therapy strategies.

Ovarian cancer cells can spread in cell form or spheral form from the surface of the ovary. Therefore, metastatic ovarian cells should survive and proliferate without ECM binding. The microenvironment of cells is dynamic and contains survival factors such as cytokines, growth factors, hormones, proteases, and ECM proteins that regulate tumor cell migration, invasion, survival, and spheral forms. ${ }^{7}$ In particular, fibronectin and vitronectin (ECM proteins) induce the formation of spheroids, adherence, and disaggregation of ovarian cancer cells. These proteins, which are disintegrated by metalloproteinase-2, increase the adhesion of ovarian cancer cells to the peritoneal region that is the nascent stage of metastasis. ${ }^{8}$

$\beta$-catenin is a multi-functional protein involve in the Wnt signal pathway, as well as adhesion via E-cadherin in epithelial cells. ${ }^{9}$ In normal epithelial cells, $\beta$-catenin binds to the E-cadherin- $\alpha$ catenin complex in adherent junctions. In the presence of Wnt signaling, however, $\beta$-catenin accumulates in the cytoplasm and then translocates to the nucleus due to activation of a large number of target genes including LEF/TCF genes. ${ }^{10}$ These activated genes are attributed to the development of some diseases, especially various types of human cancers. A number of studies showed that accumulation of $\beta$-catenin was also effective in creating a suitable microenvironment for cancer progression. ${ }^{11,12}$

Recently, it has been shown that Akt is one of the most effective regulatory proteins in the $\beta$-catenin accumulation process. In particular, $\mathrm{N}$-cadherin adhesion can lead to phosphatidylinositide 3-kinase (PI3K) mediated activation of Akt, and that might stimulate the $\beta$-catenin signaling pathway. ${ }^{13}$
Moreover, the Akt protein also phosphorylates glycogen synthase kinase 3 beta (GSK3 $\beta$ ) and leads to inactivating the function of GSK3 $\beta$. In this case, stabilization and accumulation of $\beta$-catenin is induced. ${ }^{14}$

The current study aimed to investigate the role of increased $\mathrm{Ca}^{2+}$ via tunicamycin (TN) treatment and $\beta$-catenin-Akt signaling on the binding of metastatic ovarian cancer cells (PEO-1) to fibronectin. We investigated the expression levels of integrins that play an active role in PEO-1 binding to fibronectin using flow cytometry and immunofluorescence staining. Using real-time cellular analysis (RTCA), we showed that increasing cytoplasmic calcium in PEO-1 cells influenced cell adhesion. Inhibition of the accumulation of $\beta$-catenin and Akt signaling using specific inhibitors led to inhibition of PEO-1 adhesion to fibronectin. These results suggest a link between the adhesion of PEO-1 ovarian cells and $\mathrm{Ca}^{2+}$ mobilization, and the function of Akt and $\beta$-catenin.

\section{MATERIALS AND METHODS}

\section{Cell culture}

The PEO-1 human ovarian cancer cell line was purchased from Public Health England (10032308) and cultured in RPMI 1640, $10 \%$ fetal bovine serum, $2 \mathrm{mM}$ sodium pyruvate, and $2 \mathrm{mM}$ glutamine.

\section{Detection of integrin expression}

Expression levels of $\alpha v, \alpha 4, \beta 1$, and $\beta 6$ integrin were determined using specific antibodies with flow cytometry on PEO-1 cells. The cells were incubated with a 1:200 dilution of primary antibodies against integrin subunits, subsequently washed in PBS, and incubated with a 1:200 FITC-conjugated secondary antibody for $30 \mathrm{~min}$ at $4^{\circ} \mathrm{C}$. Control cells contained either a primary antibody or an FITC secondary antibody. After washing, all samples were analyzed using a flow cytometer (Becton Dickinson, FACSAria II, Canada).

\section{Localization of integrins on cell membrane}

The localization of integrins was detected using florescence microscopy. Coverslips were coated with $50 \mu \mathrm{g} / \mathrm{mL}$ fibronectin. The cells were then seeded, washed with PBS, and fixed with $4 \%$ formaldehyde, washed again and then permeabilized with $0.1 \%$ Tween-20. After washing with PBS, the cells were treated with $1 \%$ bovine serum albumin (BSA). The cells were treated with specific primary integrin antibodies (1:200 dilution) overnight at $+4^{\circ} \mathrm{C}$, then with the FITC-conjugated secondary antibody (1:300 dilution) for $1 \mathrm{~h}$ at $+4^{\circ} \mathrm{C}$. No primary antibody was added in the control group. After washing the coverslips, they were mounted on microscope slides. The slides were examined using florescence microscopy and monitored.

\section{Binding assays}

\section{The binding rate of PEO-1 cells to fibronectin}

RTCA was used for real-time and time-dependent analysis of binding of PEO-1. RTCA measures changes in electrical 
impedance as cells attach and spread in multi-well plates covered with a gold microelectrode array. ${ }^{15}$ Electrode impedance is displayed and recorded as "cell index" values, which reflects the biologic status of the monitored cells, including the cell number, cell viability, morphology, and cell adhesion. ${ }^{16}$

Sixteen-well plates were coated with different concentrations $(1 \mu \mathrm{g} / \mathrm{mL}, 5 \mu \mathrm{g} / \mathrm{mL}, 10 \mu \mathrm{g} / \mathrm{mL}, 15 \mu \mathrm{g} / \mathrm{mL}, 25 \mu \mathrm{g} / \mathrm{mL}, 50 \mu \mathrm{g} /$ $\mathrm{mL}, 100 \mu \mathrm{g} / \mathrm{mL}$ ) of fibronectin, except the control wells. The wells were washed with PBS and then blocked with $1 \%$ BSA to inhibit non-specific binding. After a background impedance measurement, $5 \times 10^{4}$ cells/well were seeded. Impedance was monitored at 15-min intervals for $24 \mathrm{~h}$. The rate of cell adhesion was calculated according to the normalized cell index $(\mathrm{NCl})$ or cell index formula.

$\mathrm{NCl}=$ (impedance at time point $\mathrm{n}$ - impedance in the absence of cells) / nominal impedance value.

$\mathrm{Cl}=$ (resistance measured at a time point - resistance measured without the cell) / $15 \Omega$.

The role of $\left[\mathrm{Ca}^{2+}\right]$ i on PEO-1 cell adhesion capacity

Integrins on the cell surface were activated using fibronectin $(50 \mu \mathrm{g} / \mathrm{mL})$. The effect of $\left[\mathrm{Ca}^{2+}\right] \mathrm{i}$ on cell adhesion capacity was investigated using RTCA after stimulating PEO-1 cells with $\mathrm{IP}_{3}$-independent intracellular calcium release, thapsigargin (TG) $(50 \mathrm{nM}, 100 \mathrm{nM}, 500 \mathrm{nM}, 1 \mu \mathrm{M}, 2 \mu \mathrm{M})$, and extracellular calcium channel blocker TN (0,5-1-5-10-20 $\mu \mathrm{g} / \mathrm{mL})$. PEO-1 cells were treated with $5,20,35 \mathrm{mM}$ EGTA [ethylene glycol-bis( $\beta$ aminoethyl ether)-N,N,N',N'-tetraacetic acid], which is $\mathrm{Ca}^{2+}$ chelator, to create a non-calcium environment. Measurement of cell adhesion was conducted for $24 \mathrm{~h}$.

The role of cardamonin and Akt on the binding ability of PEO-1 cells

Sixteen-well plates were prepared as mentioned above. After the wells were coated with $50 \mu \mathrm{g} / \mathrm{mL}$ fibronectin, the plates were seeded with $5 \times 10^{4}$ PEO- 1 cells and transferred into RTCA for $2 \mathrm{~h}$ incubation before monitoring. After that, the cells were treated with different concentrations of cardamonin $(3,13 \mu \mathrm{M}$, $6,25 \mu \mathrm{M}, 12,5 \mu \mathrm{M}, 25 \mu \mathrm{M}, 50 \mu \mathrm{M}, 100 \mu \mathrm{M})$, an inhibitor $\beta$-catenin, and FPA $124(5 \mu \mathrm{M}, 15 \mu \mathrm{M}, 25 \mu \mathrm{M}, 35 \mu \mathrm{M})$, an Akt signal pathway inhibitor. The cells were monitored at 30-min intervals for a period of $24 \mathrm{~h}$. Uncoated wells were used as a control group together with the wells containing no inhibitor.

\section{RESULTS}

Expression and localization of integrins on the surface of PEO-1 cells

The expression and localization of $\alpha 4, \beta 1, \alpha v$, and $\beta 6$ integrin subunits were investigated using flow cytometry and immunofluorescence staining. The results of the flow cytometric analysis are given in Figure 1. The expression levels of $\alpha v, \alpha 4, \beta 6$, and $\beta 1$ were in a descending order with respect to expression level. The expression level of the $\alpha v$ integrin subunit was found to be abundant compared with the others.

PEO-1 cells were incubated with specific primary integrin antibodies and the localization of integrin subunits was demonstrated using fluorescence microscopy (Figure 2). PEO1 cells showed low but detectable level of $\beta 6$ integrin subunit localization, whereas cells exhibited considerable amounts of $\alpha 4, \alpha v$, and $\beta 1$ localizations over the whole cell as labelled with specific antibodies.

a)

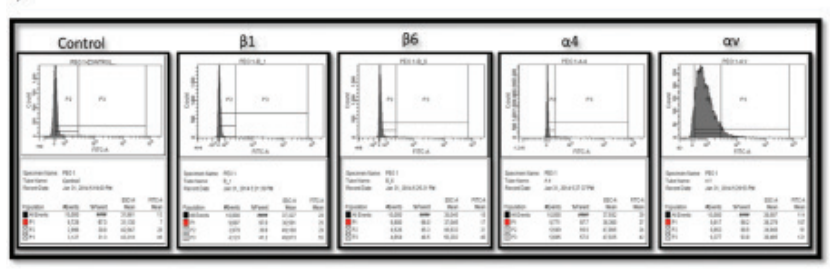

b)

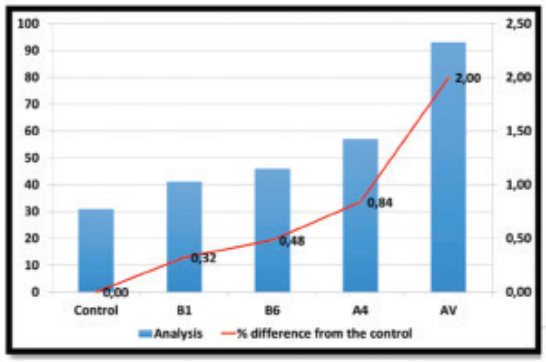

Figure 1. Flow cytometric analysis of $\alpha 4, \beta 1, \alpha v$ and $\beta 6$ integrin subunits expression (a), and percentage of integrin subunits expressions (b) on the surface of human ovarian cancer PEO-1 cell line. (a) Cells were first treated with $\alpha 4, \beta 1, \alpha v$ and $\beta 6$ primary antibodies, except the controls, and then FITC conjugated secondary antibodies. (b) The left axis is expression level, the right axis is the percentage differences from the control group. Expression levels of $\alpha 4, \beta 1, \alpha v$ and $\beta 6$ are higher by about $32 \%, 48 \%, 84 \%$, and $200 \%$ than the control group, respectively
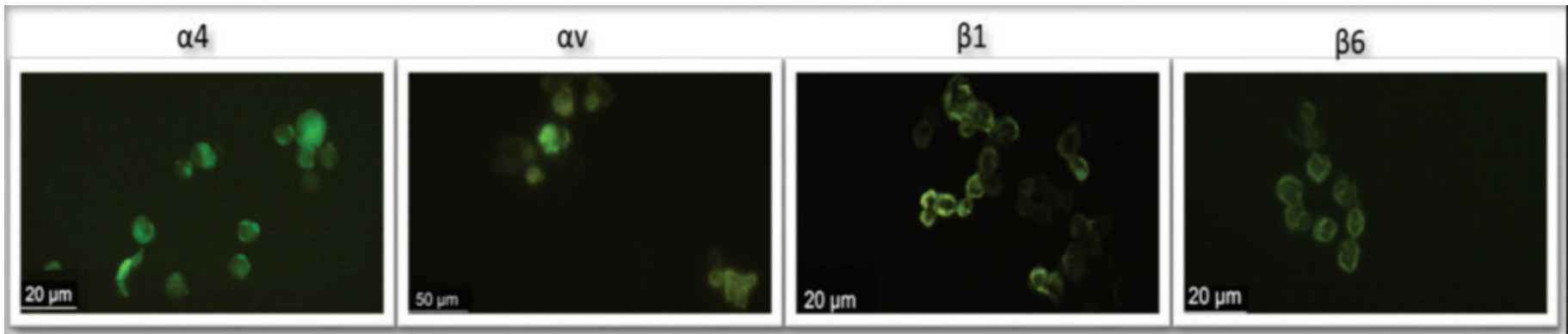

Figure 2. Immunofluorescence staining of human ovarian cancer PEO-1 cells for $\alpha 4, \alpha v, \beta 1$ and $\beta 6$ integrin subunits. The cells were labelled with various primary integrin antibodies at $37^{\circ} \mathrm{C}$ for $1 \mathrm{~h}$. After that, PEO-1 cells were incubated with FITC-conjugated secondary antibody 


\section{The binding rate of PEO-1 cells to fibronectin}

PEO-1 cells were examined using RTCA to determine the binding of cells in various concentrations $(1-100 \mu \mathrm{g} / \mathrm{mL})$ of fibronectin. The results, shown in Figure 3, indicate that PEO-1 cells bound to fibronectin at all concentrations compared with the control cells. The cells showed a higher percentage of binding to $50 \mu \mathrm{g} / \mathrm{mL}$ fibronectin (cell index 5-6 at $24 \mathrm{~h}$ ), whereas low-concentration fibronectin $(1 \mu \mathrm{g} / \mathrm{mL})$ supported little cell adhesion. The result suggests that $50 \mu \mathrm{g} / \mathrm{mL}$ fibronectin would be a suitable concentration for use in further studies.

\section{Effects of calcium on PEO-1 cell binding}

Figure 4 depicts that the involvement of $\mathrm{Ca}^{2+}$ increases in the mechanism of cell adhesion to fibronectin. PEO-1 cells were plated onto 16 -well plates that were previously coated with $50 \mu \mathrm{g} / \mathrm{mL}$ fibronectin in the presence or absence of various concentrations of TN, TG or EGTA. The results demonstrated that integrin-mediated PEO-1 adhesion to fibronectin was reduced by $\mathrm{Ca}^{2+}$ mobilization from both the extracellular and intracellular $\mathrm{Ca}^{2+}$ pool. The addition of all $\mathrm{Ca}^{2+}$ mobilization compounds resulted in a decrease in $\mathrm{Cl}$ down to zero at the $24 \mathrm{~h}$ time point because of the cells becoming rounded and detaching from the well bottom.

Figure 4a demonstrates that the change in cell index occurred within the first few hours of exposing PEO-1 cells to all concentrations of TN. The rate of adhesion of PEO-1 cells to fibronectin decreased in a dose-dependent manner. TN concentrations of 0.5 and $1 \mu \mathrm{g} / \mathrm{mL}$ indicated no effects on PEO-1adhesion ability as compared with the control cells. The proportion of adherent cells reduced to a minimal level by the presence of $20 \mu \mathrm{g} / \mathrm{mL}$ TN. The results suggest that extracellular calcium mobilization reduced the adhesion of highly metastatic PEO-1 cells to fibronectin, and might induce anoikis of PEO-1 cells; however, the latter remains unclear.

The addition of all concentrations of TG reduced cell adhesion to fibronectin in a time-dependent manner as compared with the control cells (Cl: 0.4) (Figure 4b). After 24-h incubation, even the addition of the lowest concentration ( $50 \mathrm{nM}$ ) of TG decreased the attachment of PEO-1 cells to fibronectin to zero. The results suggest that the adhesion of PEO-1 cells to fibronectin was decayed by the inhibition of the endoplasmic reticulum pump via TG treatment.

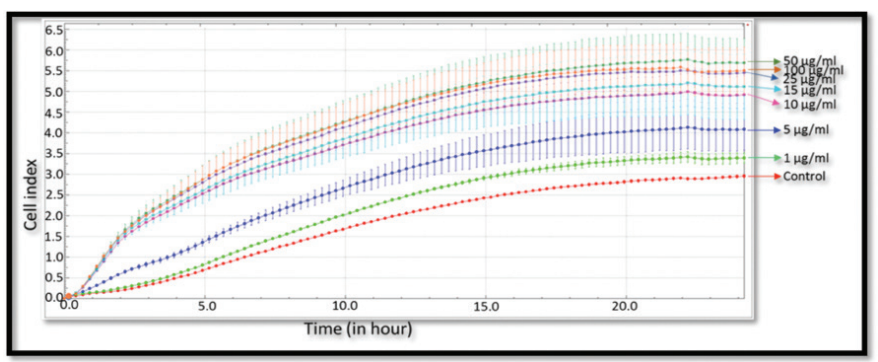

Figure 3. The binding ability of PEO-1 cells to fibronectin by RTCA. PEO-1 cells were allowed to incubate for $24 \mathrm{~h}$ on 16 -well plates coated with 1-50 $\mu \mathrm{g} / \mathrm{mL}$ fibronectin concentrations. The control wells were not coated with fibronectin. As mentioned in the Materials and Methods section, impedance was monitored at 15-min intervals for $24 \mathrm{~h}$
Treatment of PEO-1 cells with various concentrations of EGTA also reduced the rate of adhesion within $5 \mathrm{~h}$ and then remain unchanged (Figure 4c).

The role of the PKB/AKt signal pathway on PEO-1 cell binding to fibronectin

FPA-124 was used to inhibit the protein kinase B (PKB)/Akt signal pathway. The impact of inhibiting PKB/Akt on cell binding was tested with different concentrations $(5 \mu \mathrm{M}, 15 \mu \mathrm{M}, 25 \mu \mathrm{M}$, $35 \mu \mathrm{M}$ ) of FPA 124 (Figure 5). The percentage of the impact of different FPA-124 concentrations on cell binding at $24 \mathrm{~h}$ in PEO1 is given in Figure $5 b$.

Figure 5a demonstrates the attachment of the control cells (without FPA-124; $\mathrm{Cl}$ : 1.9). The cell index of the group treated with $5 \mu \mathrm{M}$ FPA-124 inhibitor is close to that of control group (Cl: 1.4 after 24-h incubation). Increasing the concentration of inhibitor by about three times showed the different effects on PEO-1 cell attachment to fibronectin. For the first few hours, cell attachment to fibronectin increased after adding $15 \mu \mathrm{M}$ FPA inhibitor; however, longer incubation times reduced the binding of PEO-1 cells to the background level ( $\mathrm{Cl}$ : 0.3). The results suggest that FPA inhibitors might cause rapid focal contacts between cell-fibronectin in a dose dependent manner. Higher
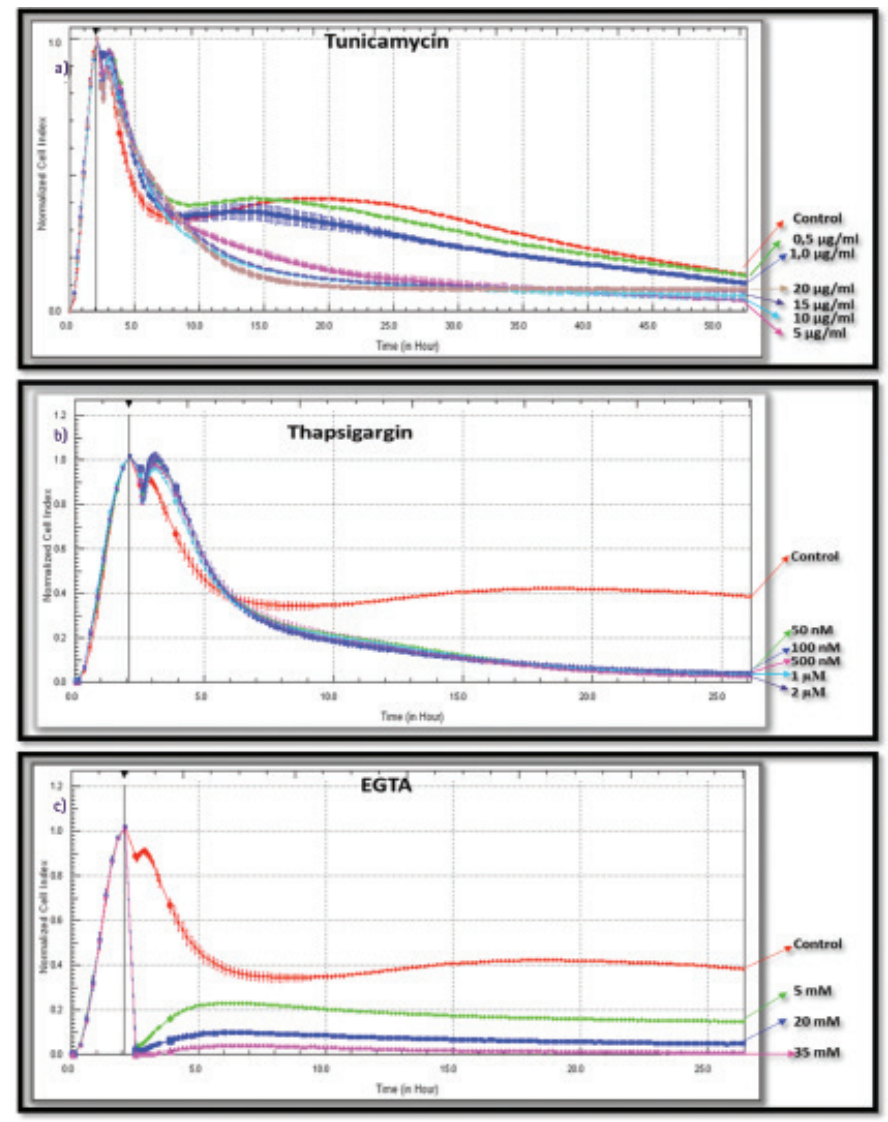

Figure 4. Effects of TN, TG and EGTA on PEO-1 binding to $50 \mu \mathrm{g} / \mathrm{mL}$ fibronectin after $24 \mathrm{~h}$. (a) PEO-1 cells were treated with 0.5-1-5-10-20 $\mu \mathrm{g} /$ $\mathrm{mL}$ of TN; (b) with 50-100-500 nM-1-2 $\mu \mathrm{M} \mathrm{TG}$ and (c) with 5-20-35 mM of EGTA for $24 \mathrm{~h}$ after being plated onto $50 \mu \mathrm{g} / \mathrm{mL}$ fibronectin. The rate of cell adhesion was calculated according to the $\mathrm{NCl}$ formula 
concentrations of FPA-124 ( 25 and $35 \mu \mathrm{M}$ ) inhibited the binding of cells to fibronectin immediately after being added to the culture medium.

\section{The role of cardamonin on PEO-1 cell binding to fibronectin}

The effects of cardamonin on PEO-1 cell binding to fibronectin were investigated using RTCA and adding various concentrations $(3.13,6.25,12.5,25,50$ and $100 \mu \mathrm{M})$ of cardamonin. The results are shown in Figure $6 \mathrm{a}$ and $\mathrm{b}$. The addition of $100 \mu \mathrm{M}$

a)

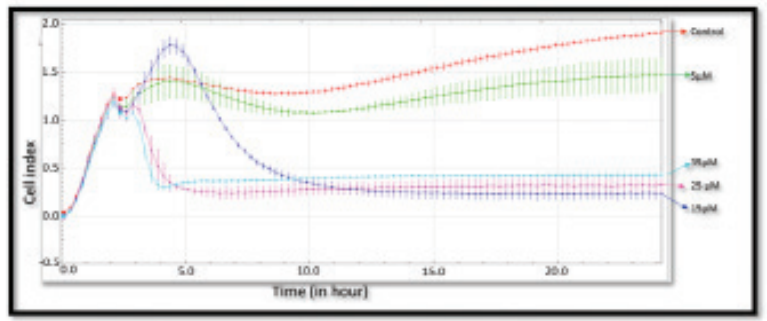

b)

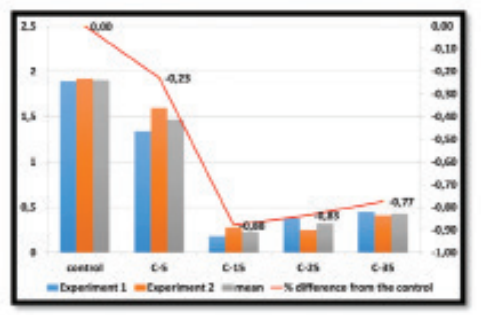

Figure 5. The role of PKB/Akt molecules on PEO-1 cell binding to fibronectin (a) and the impact of different FPA-124 concentrations on cell binding at $24 \mathrm{~h}$ (b). 16-wells plates were prepared as described in Materials and Methods. Various concentrations $(5-35 \mu \mathrm{M})$ of FPA-124 inhibitor were added to each well. No inhibitor was added to the control groups. (b) The left axis is the cell index at $24 \mathrm{~h}$, the right axis is the percentage differences from the control group

a)

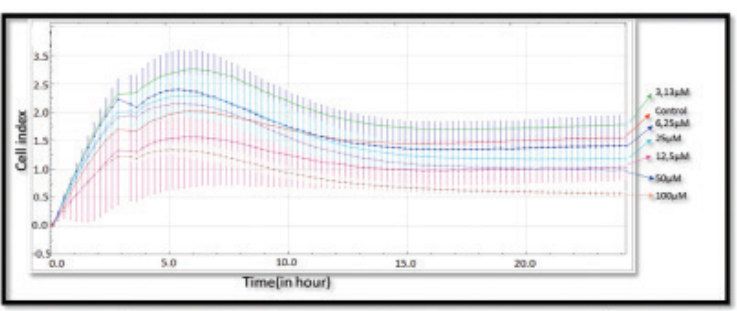

b)

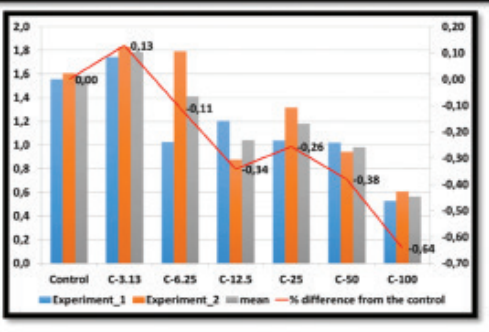

Figure 6. The effect of cardamonin on binding of PEO-1 cells to fibronectin (a) and the percentage of the impact of different cardamonin concentrations on PEO-1 cell binding to fibronectin at $24 \mathrm{~h}$ (b). Wells were coated with 50 $\mu \mathrm{g} / \mathrm{mL}$ fibronectin at $+4^{\circ} \mathrm{C}$ overnight. The cells were transferred into each well and then incubated with cardamonin (concentration range between $3.13 \mu \mathrm{M}$ and $100 \mu \mathrm{M}$ ) for $24 \mathrm{~h}$. The results represented are the means of the two wells. (b) The left axis is the cell index at $24 \mathrm{~h}$, the right axis is the percentage differences from the control group cardamonin to the cells inhibited cell binding to fibronectin by about $64 \%$. With the exception of $3.13-\mu \mathrm{M}$ cardamonin treatment, all other concentrations of cardamonin inhibited cell binding to fibronectin as compared with the control cells plated on uncoated wells. Treatment of cells with the lowest concentration $(3.13 \mu \mathrm{M})$ of cardamonin stimulated the rate of cell binding to fibronectin at around $13 \%$ as compared with the control cells. The results showed that the degradation of $\beta$-catenin in the cytoplasm by cardamonin had an important role in PEO-1 cell binding to fibronectin.

\section{DISCUSSION}

Adhesion and integrin activation are important to metastasize ovarian cancer cells onto the peritoneal mesothelial surface of the abdominal cavity ${ }^{17}$, and in the resistance to anoikis of epithelial ovarian cancer spheroids. It has been reported that some binding proteins might be involved in the implantation of ovarian cancer metastasis. ${ }^{18}$ CD44 in particular, which is a receptor for the ECM protein hyaluronic acid, plays a crucial role in mediating the mesothelial binding of ovarian cancer cells and $\beta 1$ integrins such as $\alpha 5 \beta 1$ integrin (a receptor for fibronectin), $\alpha 3 \beta 1$ (a receptor for fibronectin, collagen and laminin) and $\alpha v$ (a receptor for fibronectin and vitronectin) expressed by ovarian cancer cells; and ovarian cancer cell binding to peritoneal mesothelium. ${ }^{18}$ In our experiment, we found that the expression level of $\alpha v$ was two-fold higher than in the control group in PEO-1 cells. The other integrin expression levels of $\alpha 4, \beta 1$, and $\beta 6$ subunits were higher at around $32 \%, 48 \%$, and $84 \%$, respectively, than in the control group. The $\alpha v \beta 1$ fibronectin receptor most likely contributes to integrin-mediated binding of PEO-1 cells. These results are consistent with previous findings. Carduner et al. ${ }^{19}$ reported that $\alpha v$ had an important role in ovarian cancer progression. Lessan et al. ${ }^{20}$ informed that $\beta 1$ integrin may responsible for adhesion of ovarian cancer cells.

Fibronectin has been detected in ovarian cancer cell metastases and is also present in ascites. 21,22 Fibronectin contributes to the formation, adhesion, and disaggregation of ovarian cancer cell spheroids. ${ }^{23}$ Therefore, the investigation of the binding capacity of ovarian cancer cells to fibronectin should be useful for targeted therapies. The binding studies herein suggest that PEO-1 cells could be able to adhere to fibronectin in a dose dependent-manner and the maximum binding rate was reached after adhesion of cells to $50 \mu \mathrm{g} / \mathrm{mL}$ fibronectin. The binding capacity of PEO-1 cells was also measured in the presence or absence of calcium because integrin-mediated cell adhesion is regulated by extracellular $\mathrm{Ca}^{2+}$ ions ${ }^{24}$, and an increased calcium concentration in the cytoplasm is essential for various signal transduction pathways such as proliferation and apoptosis and thus is also crucial in cancer. ${ }^{25} \mathrm{TN}$ induces endoplasmic stress by inhibiting glycosylation and leads to the accumulation of unfolded proteins. Endoplasmic stress has a critical role in regulating cell death. ${ }^{26}$ Our results clearly indicated that increased calcium levels in the cytoplasm of PEO-1 cells by either extracellular or intracellular stores was essential for the binding of these cells to fibronectin. Increasing intracellular calcium in PEO-1 cells reduced cell adhesiveness and also 
might have caused programmed cell death induced after cell detachment from the ECM.

$\mathrm{PKB} / \mathrm{Akt}$ is a serine/threonine kinase that has an important role in cell survival, cell proliferation, invasion, and adhesion to the ECM in various types of cells such as human umbilical vein endothelial cells ${ }^{27}$, breast cancer cell ${ }^{28}$, and lung adenocarcinoma. ${ }^{29}$ The overexpression of PI3K/Aktrelated genes has been observed in ovarian cancer tissues. ${ }^{30}$ Moreover, fibronectin adhesion promotes metastatic behavior on these types of cancer cells through the focal adhesion kinase-PI3K/Akt pathway. ${ }^{31}$ Xing et al. ${ }^{32}$ suggested that Akt activation promoted by fibronectin might have a critical role in cell survival. In the present study, inhibition of PKB/Akt with the FPA inhibitor decreased the rate of adhesion of PEO-1 cells to fibronectin in a dose dependent manner, suggesting that PKB/ Akt participates in the signaling of adhesion in these cells.

In the present study, we found that the inhibition of $\beta$-catenin by cardamonin reduced PEO-1 cell binding to fibronectin. $\beta$-catenin is an activated downstream signal molecule from Akt, and Akt-mediated phosphorylation of $\beta$-catenin results in its accumulation in the cytosol and translocation into the nucleus, thus upregulating genes related to cell proliferation such as c-Myc, cyclin D1 and D2. ${ }^{33}$ The function of $\beta$-catenin may be necessary for the adhesive and signaling responses required for cancer. The inhibition of $\beta$-catenin activity causes suppression of several cancer hallmarks, which might be useful as a putative drug target. ${ }^{34}$ Pramanik et al..$^{35}$ found that inhibition of $\beta$-catenin signaling blocked pancreatic tumor growth. Verma et al. ${ }^{36}$ showed that small interfering RNAs directed against $\beta$-catenin reduced $\beta$-catenin-dependent gene expression and growth of colon cancer cells. In this study, we found that the binding ability of PEO-1 ovarian cells to fibronectin decreased with treatment of $100 \mu \mathrm{M}$ cardamonin, suggesting that $\beta$-catenin might be involved in the adhesion process of PEO-1 cells to fibronectin as well as Akt. This process could be mediated by integrin, especially the $\alpha v$ subunit, but further experiments are required to investigate the role of the $\alpha v$ subunit under these circumstances.

\section{CONCLUSION}

In conclusion, PEO-1 cell binding to fibronectin via integrins could be related to intracellular $\mathrm{Ca}^{2+}$ mobilization and Akt signaling. However, the sensitivity of these cells against anoikis still remains to be investigated.

\section{ACKNOWLEDGEMENTS}

This work was funded by grants from the Anadolu University (Project No. 1308 S303 and 1301S011). The authors wish to thank Anadolu University, Medicinal Plants, Drugs and Scientific Research Center (AÜBIBAM) for technical support. Earlier versions of this paper were presented at the $40^{\text {th }}$ FEBS Congress, The Biochemical Basis of Life, Berlin, Germany, July 4-9, 2015 and at the International Multidisciplinary Symposium on Drug Research and Development, Eskişehir, Turkey, 15-17 October, 2015. The abstract of this paper was published at the FEBS Journal, 282 (Suppl 1), 286, July 2015.
Conflict of Interest: No conflict of interest was declared by the authors.

\section{REFERENCES}

1. Manso AM, Kang SM, Ross RS. Integrins, Focal Adhesions and Cardiac Fibroblasts. J Investig Med. 2009;57:856-860.

2. Aoudjit F, Vuori K. Integrin Signalling in Cancer Cell Survival and Chemoresistance. Chemotherapy Res and Pract. 2012;2012:1-16.

3. Hirohashi S, Kanai Y. Cell adhesion system and human cancer morphogenesis. Cancer Sci. 2003;94:575-581.

4. van den Hoogen $\mathrm{C}$, van der Horst $\mathrm{G}$, Cheung $H$, Buijs JT, Pelger RC, van der Pluijm G. Integrin av expression is required for the acquisition of a metastatic stem/progenitor cell phenotype in human prostate cancer. Am J Pathol. 2011;179:2559-2568.

5. Paoli P, Giannoni E, Chiarugi P. Anoikis molecular pathways and its role in cancer progression. Biochimica et Biophysica Acta-Molecular Cell Research. 2013;1833:3481-3498.

6. Lu JG, Li Y, Li L, Kan X. Overexpression of osteopontin and integrin $\alpha v$ in laryngeal and hypopharyngeal carcinomas associated with differentiation and metastasis. J Cancer Res Clin Oncol. 2011;137:1613-1618.

7. Puiffe ML, Le Page C, Filali-Mouhim A, Zietarska M, Ouellet V, Tonin PN, Chevrette M, Provencher DM, Mes-Masson AM. Characterization of ovarian cancer ascites on cell invasion, proliferation, spheroid formation, and gene expression in an in vitro model of epithelial ovarian cancer. Neoplasia. 2007;9:820-829.

8. Kenny HA, Kaur S, Coussens LM, Lengyel E. The initial steps of ovarian cancer cell metastasis are mediated by MMP-2 cleavage of vitronectin and fibronectin. J Clin Invest. 2008;118:1367-1379.

9. Bodnar L, Stanczak A, Cierniak S, Smoter M, Cichowicz M, Kozlowski W, Szczylik C, Wieczorek M, Lamparska-Przybysz M. Wnt/ $\beta$-catenin pathway as a potential prognostic and predictive marker in patients with advanced ovarian cancer. J of Ovarian Research. 2014;7:16-26.

10. Hur J, Jeong S. Multitasking $\beta$-catenin: From adhesion and transcription to RNA regulation. Animal Cell Systems. 2013;17:299-305.

11. Uchino M, Kojima H, Wada K. Nuclear beta-catenin and CD44 upregulation characterize invasive cell populations in non-aggressive MCF-7 breast cancer cell. BMC Cancer. 2010;10:414-417.

12. Chau WK, Ip CK, Mak AS. C-Kit mediates chemoresistance and tumorinitiating capacity of ovarian cancer cells through activation of Wnt/betacatenin-ATP-binding cassette G2 signaling. Oncogene. 2012;10:103-107.

13. Tran NL, Adams DG, Vaillancourt RR, Heimark RL. Signal transduction from $\mathrm{N}$-cadherin increases $\mathrm{Bcl}-2$. Regulation of the phosphatidylinositol 3-kinase/Akt pathway by homophilic adhesion and actin cytoskeletal organization. J Biol Chem. 2002;277:32905-32914.

14. Sharma M, Chuang WW, Sun Z. Phosphatidylinositol 3-kinase/Akt stimulates androgen pathway through GSK3beta inhibition and nuclear beta-catenin accumulation. J Biol Chem. 2002;277:30935-30941.

15. Rahim S, Üren A. A real time electrical impedance based technique to measure invasion of endothelial cell monolayer by cancer cells. J Vis Exp. 2011;50:2792-2797.

16. Zhang JD. 2016. Available from: https://www.bioconductor.org/ packages/devel/bioc/vignettes/RTCA/inst/doc/aboutRTCA.pdf.

17. Sawada K, Mitra AK, Radjabi AR, Bhaskar V, Kistner EO. Tretiakova M, Jagadeeswaran S, Montag A, Becker A, Kenny HA. Loss of E-cadherin promotes ovarian cancer metastasis via $\alpha$-integrin, which is a therapeutic target. Cancer Res. 2008;68:2329-2339. 
18. Strobel T, Cannistra S. B1-Integrins partly mediated binding of ovarian cancer cells to peritoneal mesothelium in vitro. Gynecologic Oncology. 1999;73:362-367.

19. Carduner L, Leroy-Dudal J, Picot CR, Gallet O, Carreiras F, Kellouche S. Ascites-induced shift along epithelial-mesenchymal spectrum in ovarian cancer cells: enhancement of their invasive behaviour partly dependant on av integrins. Clinical and Experimental Metastasis. 2014;31:675-688.

20. Lessan K, Aguiar DJ, Oegema T, Siebenson L, Skubitz AP. CD44 and $\beta 1$ integrin mediate ovarian carcinoma cell adhesion to peritoneal mesothelial cells. Am J Pathol. 1999;154:1525-1537.

21. Bignotti E, Tassi RA, Calza S, Ravaggi A, Bandiera E, Rossi E, Donzelli C, Pasinetti B, Pecorelli S, Santin AD. Gene expression profile of ovarian serous papillary carcinomas: identification of metastasis-associated genes. Am J Obstet Gynecol. 2007;196:245.

22. Wilhelm O, Hafter R, Coppenrath E, Pflanz M, Schmitt M, Graeff H. Fibrin-fibronectin compounds in human ovarian tumor ascites and their possible relation to the tumor stroma. Cancer Res. 1988;48:3507-3514.

23. Mitra AK, Sawada K, Tiwari P, Mui K, Gwin K, Lengyel E. Ligandindependent activation of $\mathrm{c}$-Met by fibronectin and $\alpha(5) \beta(1)$-integrin regulates ovarian cancer invasion and metastasis. Oncogene. 2011;30:1566-1576.

24. Tsaktanis T, Kremling H, Pavsic M, von Stackelberg R, Mack B, Fukumori A, Steiner H, Vielmuth F, Spindler V, Huang Z, Jakubowski J, Stoecklein $\mathrm{NH}$, Luxenburger E, Lauber K, Lenarcic B, Gires O. Cleavage and cell adhesion properties of human epithelial cell adhesion molecule (HEPCAM). The Journal of Biological Chemistry. 2015;290:24574-24591.

25. Giorgi C, Bonova M, Pinton P. Inside the tumor: p53 modulates calcium homeostasis. Cell Cycle. 2015;147:933-934.

26. Nami B, Donmez H, Kocak N. Tunicamycin-induced endoplasmic reticulum stress reduces in vitro subpopulation and invasion of CD44+/CD24- phenotype breast cancer stem cells. Exp Toxicol Pathol. 2016;68:418-426.

27. Hwang HJ, Chung HS, Jung TW, Ryu JY, Hong HC, Seo JA, Kim SG, Kim NH, Choi KM, Choi DS, Baik SH, Yoo HJ. The dipeptidyl peptidaseIV inhibitor inhibits the expression of vascular adhesion molecules and inflammatory cytokines in HUVECs via Akt- and AMPK-dependent mechanisms. Mol Cell Endocrinol. 2015;405:25-34.
28. Leung HW, Wang Z, Yue GG, Zhao SM, Lee JK, Fung KP, Leung PC, Lau $\mathrm{CB}$, Tan NH. Cyclopeptide RA- $\mathrm{V}$ inhibits cell adhesion and invasion in both estrogen receptor positive and negative breast cancer cells via PI3K/AKT and NF-KB signaling pathways. Biochim Biophys Acta. 2015;1853:1827-1840.

29. Piegeler T, Schlapfer M, Dulli RO, Schwartz DE, Borgeat A, Minshall RD, Beck-Schimmer B. Clinically relevant concentrations of lidocaine and ropivacaine inhibit TNFa-induced invasion of lung adenocarcinoma cells in vitro by blocking the activation of Akt and focal adhesion kinase. $\mathrm{Br} J$ Anaesth. 2015;115:784-791.

30. Gwak H, Kim S, Dhanasekaran DN, Song YS. Resveratrol triggers ER stress-mediated apoptosis by disrupting N-linked glycosylation of proteins in ovarian cancer cells. Cancer Lett. 2016;371:347-353.

31. Yousif NG. Fibronectin promotes migration and invasion of ovarian cancer cells through up-regulation of FAK-PI3K/Akt pathway. Cell Biol Int. 2013;38:85-91.

32. Xing $H$, Weng $D$, Chen G, Tao W, Zhu T, Yang X, Meng L, Wang S, Lu Y, $\mathrm{Ma}$ D. Activation of fibronectin/PI-3K/Akt2 leads to chemoresistance to docetaxel by regulating survivin protein expression in ovarian and breast cancer cells. Cancer Lett. 2008;261:108-119.

33. Fang D, Hawke D, Zheng Y, Xia Y, Meisenhelder J, Nika H, Mills GB, Kobayashi R, Hunter T, Lu Z. Phosphorylation of beta-catenin by AKT promotes beta-catenin transcriptional activity. J Biol Chem. 2007;282:11221-11229.

34. Luu HH, Zhang R, Haydon RC, Rayburn E, Kang Q, Si W, Park JK, Wang H, Peng Y, Jiang W, He TC. Wnt/beta-catenin signalling pathway as a novel cancer drug target. Curr Cancer Drug Targets. 2004;4:653-671.

35. Pramanik KC, Fofaria NM, Gupta P, Ranjan A, Kim SH, Srivastava SK. Inhibition of $\beta$-catenin signaling suppresses pancreatic tumor growth by disrupting nuclear $\beta$-catenin/TCF-1 complex: critical role of STAT-3. Oncotarget. 2015;6:11561-11574.

36. Verma UN, Surabhi RM, Schmaltieg A, Becerra C, Gaynor RB. Small Interfering RNAs Directed against $\beta$-Catenin Inhibit the in vitro and in vivo Growth of Colon Cancer Cells. Clin Cancer Res. 2003;9:1291-1300. 